\title{
The Influence of Contemporary Art on the Interior of the Bar and Lounge at Hotel Artotel Thamrin Jakarta
}

\author{
Aerilia Dwiyana B. K..$^{*}$ Adi Ismanto ${ }^{1}$ Aing R. Nayadilaga ${ }^{1}$ \\ ${ }^{1}$ Interior Design Program, Faculty of Visual Art and Design, Universitas Tarumanagara, Jakarta 11440, Indonesia \\ *Corresponding author. Email: aerilia.615170095@stu.untar.ac.id
}

\begin{abstract}
Currently the number of tourists in a number of areas and business areas has increased, thus affecting the number of hotels available. This shows that the lifestyle in society has developed. Therefore, hotel managers are competing to find creativity and innovation to create attractiveness in the hotel. Hotel Artotel Thamrin Jakarta is a 4-star hotel that has the concept of combining hospitality and art. So that the concept of contemporary art on the exterior and interior of Hotel Artotel is very important. In this study, researchers used descriptive research methods with a quantitative approach to the influence of contemporary art on the interior of the Bar and Lounge Hotel Artotel. The data obtained in this study is through a survey by distributing questionnaires to respondents. From the results of these studies, it is found that the Hotel Artotel cannot be separated from art which is an identity and attraction. This was explained through a questionnaire given to 20 respondents who gave the opinion that the Artotel Hotel was an artsy hotel that had appeal.
\end{abstract}

Keywords: Hotel, Interior, Bar \& Lounge, Art, Contemporary

\section{INTRODUCTION}

Currently, hotels are a necessity in big cities, especially Jakarta. It's become a lifestyle trend (lifestyle) and the needs of the many events. With the increase in tourism in a number of regions and business areas, the number of hotels available will also increase. The mushrooming of start-up travel tours and online hotel bookings shows that the need for urban life styles for Indonesians is growing. Therefore, hotel managers are competing to find creativity and innovation to attract consumers with various kinds of creativity, including food menus, presentation methods, services, providing comfortable rooms, unique facilities, and unique and attractive interior design styles.

The main function of the hotel is as a means to meet the needs of guests (tourists or riding) as a temporary residence while away from their place of origin. But now, the function of a hotel is not only as a place to stay or rest for guests, its function has increased as a destination, seminars, workshops, national meetings and other such activities which of course provide complete facilities and infrastructure.

According to Lawson (1995, p. 27) [5], hotels are a common means of residence for tourists by providing room service, food and beverage providers and accommodation on payment terms. The location of Hotel Artotel which is in the middle of the city makes this hotel attractive because of its location which is quite close to tourist attractions in Jakarta.

Similar to hotels in general, Hotel Artotel has standard facilities that can provide satisfaction to visitors, one of which is bar and lounge facilities. Lounge sitting areas are a necessary area and adjacent to the lobby usually occupies about $10 \%$ of this space. The lounge should be clearly visible but separate from the reception and circulation areas. In smaller and middle-class hotels, the service is usually rationalized into a public lounge-bar located near the entrance. The existence of a lounge is usually tailored to the needs of the hotel based on its location. The lounge is used as a free and relaxing area which is an attractive and informal area.

\section{BACKGROUND}

Hotel Artotel Thamrin Jakarta Pusat comes with a uniqueness as an attraction, using the concept of contemporary art in its building and interior. Minister of Education, Nadiem Makarim stated that art is a human expression that cannot be ignored from character education in the education system in this country. Because creativity is indispensable role in negotiating the industrial revolution 4.0. With the standard of a 4-star hotel, Hotel Artotel is able to read trends and attract millennials with the arts in the hotel interior [1].

Contemporary art is a development of art that is influenced by modernization and is used as a general term since the term Contemporary Art developed in the West as a product of art created since World War II. According to Djojosudarmo (2000, p. 41) [4] the term contemporary itself comes from the word Contemporary which means anything or those who lived at the same time. 
The development of contemporary art, in its understanding and practice, does not only contain elements of tradition. However, growing more aggressively explore the possibilities of future human experience that is driven by the interaction of economic development and the development of a global information technology.

Hotel Artotel Thamrin, Central Jakarta, invites Indonesian artists to collaborate on the application of art to the hotel interior in the bar and lounge area. These artists include Eko Nugroho, Naela Ali, Sarkodit, and Resatio. These artists are 2D art artists who will decorate the hotel interior with mural art. In addition, there are also artists with 3D works such as Ira Suryandari, Adhy Putraka, and Ayu Larasati. With the main concept that combines art and hospitality, the artists use their works of fine art in hotel interiors such as floors, walls, and ceilings. These artists also act as a link between ideas and realization to present a hotel that is unique and attractive as well as introducing young Indonesian artists.

\section{METHODS}

Research on the Influence of Contemporary Art on the Interior of Bar and Lounge Hotel Artotel which is located at Jalan Sunda No.3, Gondangdia, Kec. Menteng, Central Jakarta City, close to Sarinah Thamrin Mall, Djakarta XXI, Plaza Indonesia Mall, Tanah Abang Market, Thamrin City, Bundaran HI MRT Station and Transjakarta bus stops. Artotel Hotel is a business hotel because of its location close to downtown and to the tourists who were on a business trip (business / trade).

The research was conducted in December 2020. Hotel Artotel is a 4-star hotel located in Thamrin, Central Jakarta, chosen as the object of research, because this hotel has an appeal through a concept that combines hotel and art. Contemporary art was chosen because its development, in its understanding and practice, not only contains elements of tradition, but develops more aggressively in exploring the possibilities of human experience in the future which is driven by the interaction of economic development and the development of a global information technology.

Research on the application of contemporary art at Hotel Artotel uses descriptive methods with a quantitative approach. According to Nazir (2002, p. 41) [6] The descriptive method is a method in researching the status of a group of people, an object, a set of conditions, a system of thought or a class of events in the present. This research approach is a quantitative research. Quantitative research methods can be defined as a method used to examine a particular population or sample, data collection using research instruments, statistical data analysis, with the aim of testing predetermined hypotheses.

This research is a field research which is meant to obtain secondary data in the organization. Data collection by observation and questionnaires. Observation is the author's way of being able to use the objective conditions of various things to be the research target, namely conducting a direct review to the research location in order to observe the research objects. Literature study by reading books, journals, e-books, and e-journals, to collect concepts and theories about contemporary art, hotel interiors, and related ones. In the opinion of Rukajat A. (2018) [7] suggests that a questionnaire is a data collection technique using a set of questions that are structured to be asked to respondents.

\section{FINDINGS AND DISCUSSIONS}

Artotel Hotel is a business hotel, is part of the Artotel Group, has an area of $4657 \mathrm{~m}^{2}$ with with 104 room facilities, divided into 3 types, according to user needs. Apart from bedroom facilities, Hotel Artotel also has a meeting room facility called Meetspace, which can accommodate 100 people. The hotel is equipped with Restaurant facilities, a Rooftop Bar which is open to the public and facilities to suit the needs of users, one of which is a bar and lounge. Bar and lounge Hotel Artotel Thamrin is located on the 1st floor of the hotel which is located to the right of the hotel entrance. With an area of $345 \mathrm{~m} 2$, the bar and lounge area has a capacity of up to 70 people. The interior concept of Hotel Artotel Thamrin is an oasis that describes a pleasant place that is in an unsupportive / bad state. By taking the theme Mindful Living which focuses on peace of mind with a pleasant lifestyle. In accordance with the image of Hotel Artotel, that combines hospitality and art, in this study, the researcher will examine the influence of contemporary art on the interior of the bar and lounge at the Hotel Artotel Thamrin Jakarta.

Art is anything that is done by people not based on their basic needs, but is anything that is done solely because of the desire for luxury, enjoyment, or because of a spiritual encouragement (Susanto, 2002, p. 354) [10]. Through the theory above, it can be concluded that art is a human medium in interacting with everything (Wicaksana, 2019, p. 345) [12].

A set of values that determines what is appropriate to convey by expression through that medium, to convey either beliefs, ideas, sensations or feelings in the most effective way possible for that medium (Bujung, Betteng, \& Erdiono, 2015, p. 184) [2]. However, many artists have had influence from other people, the past, and also some guidelines have emerged to express certain ideas through symbolism and form (such as the red rose which means love). Art by means / media for art delivery (communication) used is divided into 3 kinds, namely:

1. Art that can be enjoyed through listening media or (audio art), for example music, sound, and literary arts such as poetry and rhymes.

2. Art that is enjoyed with visual media such as paintings, posters, art, buildings, martial arts and so on.

3. Art that is enjoyed through visual and auditory media (audio visual art) such as music performances, puppet shows, films.

The word "Contemporary" comes from the word "co" (together) and "tempo" (time). So that it emphasizes that 
contemporary art is a work that thematically reflects the situation of the time being passed. The characteristics of contemporary art include the following:

1. There are no boundaries between the various art disciplines, ex: the fusion of the boundaries between painting, sculpture, graphics, crafts, theater, music, anarchism, to political action.

2. The concept of creation is still based on a philosophy, but the range of visualization is unlimited.

3. Not bound by certain rules and regulations of the past, but developing according to the times.

4. Having passion and moralism related to social and political dimensions as a thesis.

5. Art that tends to be of interest to the mass media to become a commodity for discourse as a fashionable news actuality.

6. Prioritizing new media arts such as installation, photography, video, fiber art and accepting craft and popular arts.

7. Issues discussed in contemporary art, for example: gender, human rights, multiculturalism, ethnic culture, environment, and others.

According to Wicaksana (Wicaksana, 2019) [12], there are two fundamental aspects behind the understanding of contemporary art prevailing in Indonesia. The first aspect leads to the understanding of contemporary art as an alternative art, with new mediums of expression such as installation, performance art, video art, and environmental art.

The second aspect is contemporary art as art that opposes or rejects modern art (anti-modernism). Contemporary art really appreciates plurality, is oriented freely, ignores rigid boundaries. Contemporary art can be created from various objects, materials, or media, there is no differentiation between one another, including objects that already exist in everyday life.

The thing that is most closely related to the world of art is the environment and human anxiety with something that they experience and feel which is then channeled through the media, and that medium is called a work of art. Fine art is a branch of art whose work can be enjoyed by the eye and touched by hand. This fine art is divided into 2 , namely two-dimensional art in the form of paintings and photographs, then three-dimensional art in the form of sculptures and jars.

In the interior of the bar and lounge Hotel Artotel Thamrin, art used a 2D art consisting of paintings and murals by Eko Nugroho. Mural is drawing or painting on a relatively broad media wall. According to Priyanto Sunarto, senior lecturer at the Visual Communication Study Program of the Faculty of Fine Arts and Design (FSRD) ITB, drawing walls or murals when it started from the church. Earlier in the Gothic era, the churches in Europe looked haunted. Artists don't just draw on the walls in rooms and public areas. These symptoms occur evenly in western countries. Priyanto gave an example of the activities of artists painting walls in a slum area in New York, United States. Slums are usually dark and prone to crime. Changing the atmosphere after the walls were drawn, the atmosphere turned cheerful and people felt at home living in the area. This indicates that mural painting can influence people's psychology.

In the interior of the bar and lounge Hotel Artotel Thamrin, art used a 3D art is art ceramic vase as a form of interior decoration works Adhy Putraka and Ayu Larasati. Ceramics come from the Greek word keramos which means glassware or items from the ground that are burned. This is intended to show goods other than metal that are produced by means of the combustion process. Thus, it is clear that what is meant by the term keramos is goods made from clay through a combustion process (above a temperature of $600{ }^{\circ} \mathrm{C}$ ), Yana, D. (2014: 352-363) [13].

Contemporary art fits perfectly with the image of the hotel because based on its characteristics, this art is always up to date and free. In the picture below, you can see the interior of the bar and lounge at Hotel Artotel Thamrin Jakarta, which uses contemporary $2 \mathrm{D}$ and $3 \mathrm{D}$ art visible on the walls as well as decorations.

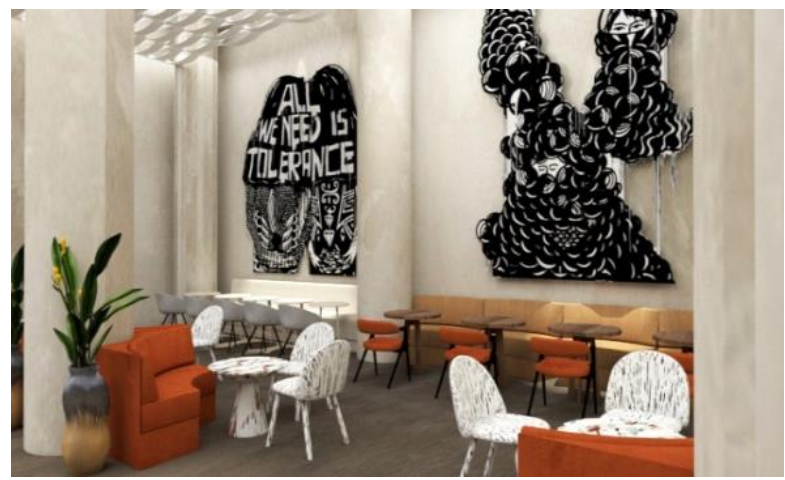

Figure 1 The interior of the Bar \& Lounge Hotel Artotel Thamrin with contemporary art

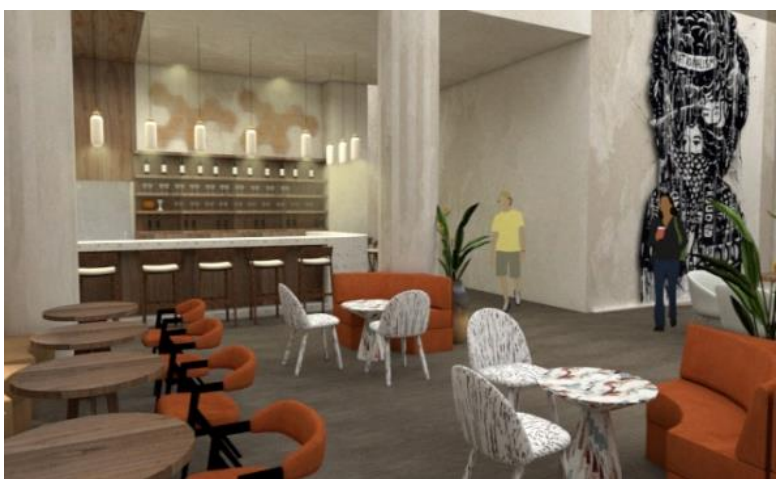

Figure 2 The interior of the Bar \& Lounge Hotel Artotel Thamrin with contemporary art 


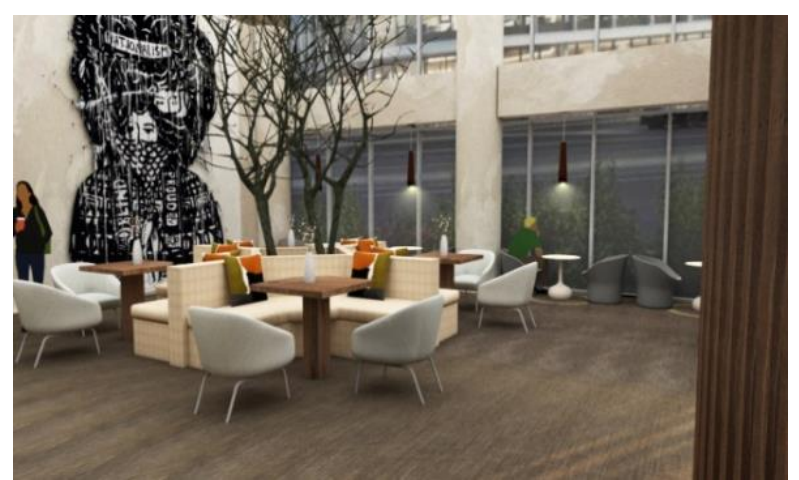

Figure 3 The interior of the Bar \& Lounge Hotel Artotel Thamrin with contemporary art

The following is the interior of the bar and lounge Hotel Artotel Thamrin Jakarta without using contemporary art in the interior.

By using a figure of the interior space of the Bar and Lounge Hotel Artotel Thamrin Jakarta, the researcher will examine how contemporary art influences the interior of the Artotel Thamrin Hotel bar and lounge. This study will use a questionnaire that will be given to 20 respondents to determine the influence of contemporary art which is the image of the Hotel Artotel.

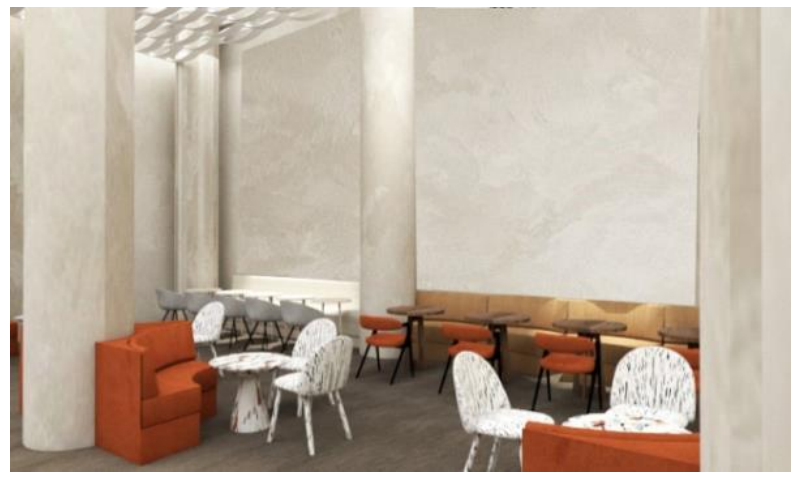

Figure 4 The interior of the Bar \& Lounge Hotel Artotel Thamrin without contemporary art

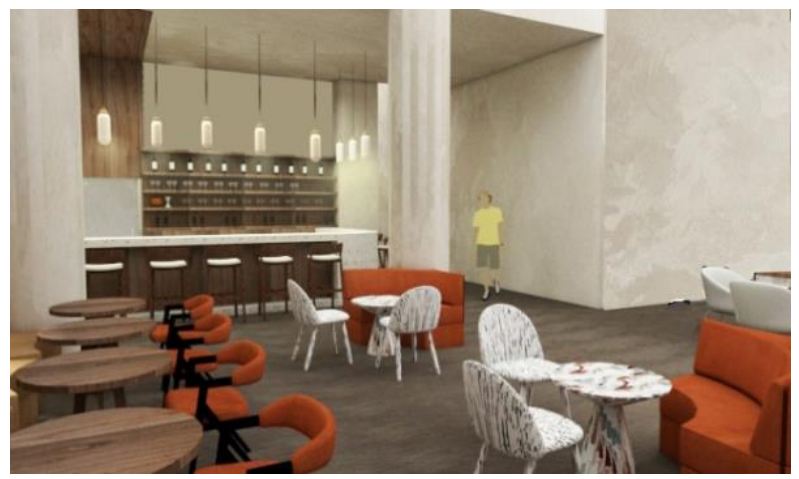

Figure 5 The interior of the Bar \& Lounge Hotel Artotel Thamrin without contemporary art

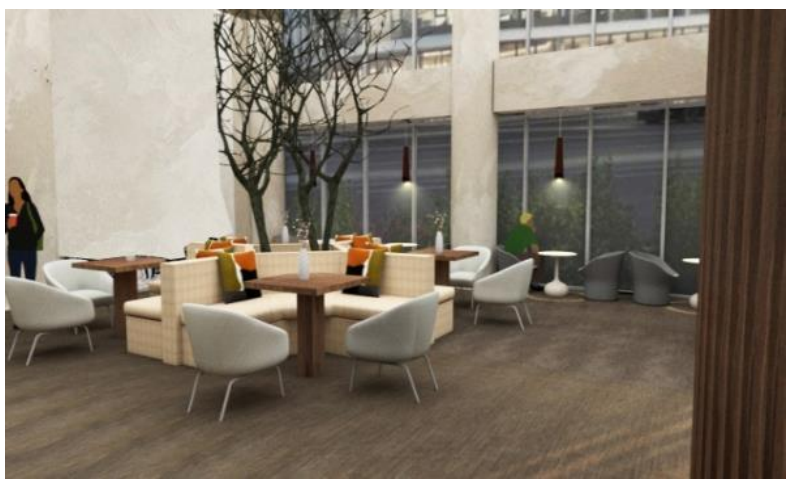

Figure 6 The interior of the Bar \& Lounge Hotel Artotel Thamrin without contemporary art

After conducting a survey through questionnaires to 20 respondents from various backgrounds and ages, many of the respondents expressed their opinion when they heard about Hotel Artotel. According to them, Hotel Artotel is a hotel related to art, especially in buildings that have murals which are also modern hotels.

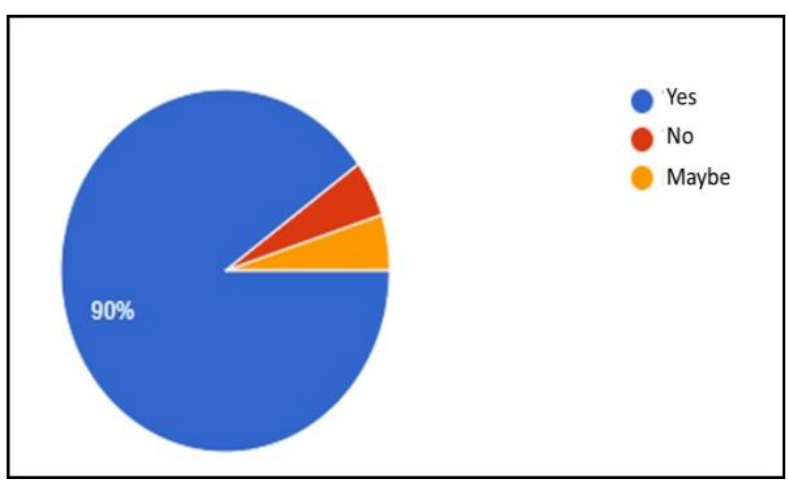

Figure 7 Survey Results of Respondents to Hotel Artotel

Based on the survey, showed that approximately $90 \%$ of respondents are interested in the concept of Hotel Artotel the use of art in its interior. Then in the next survey, respondents were given a picture of the interior view of the Bar and Lounge Hotel Artotel which was decorated with contemporary art such as the use of mural art on the walls, wickerwork, and art vase decorations.

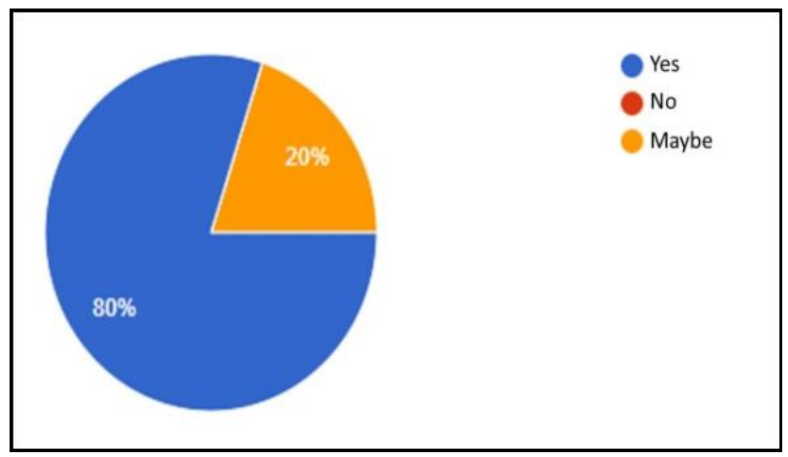

Figure 8 Survey Results of Respondents to Hotel Artotel 


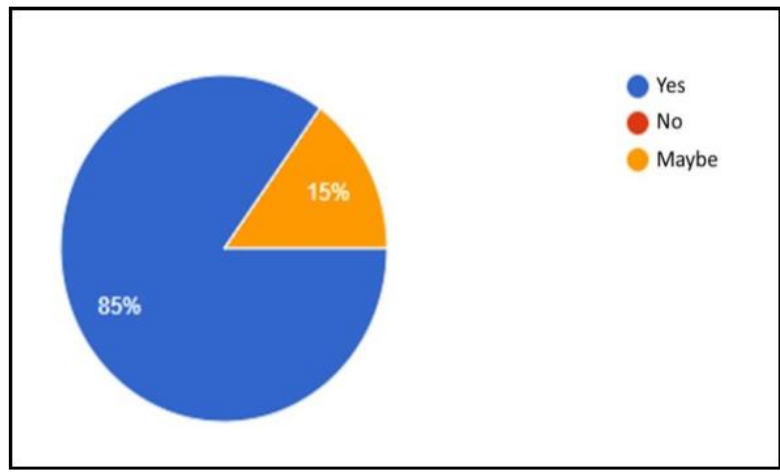

Figure 9 Survey Results of Respondents to Hotel Artotel

The survey results indicate that about $82.5 \%$ of respondents are interested in the interior of the bar and lounge Hotel Artotel with the use of art. Then the respondent was also given a picture of the interior view of the Bar and Lounge Hotel Artotel without the use of art in the interior.

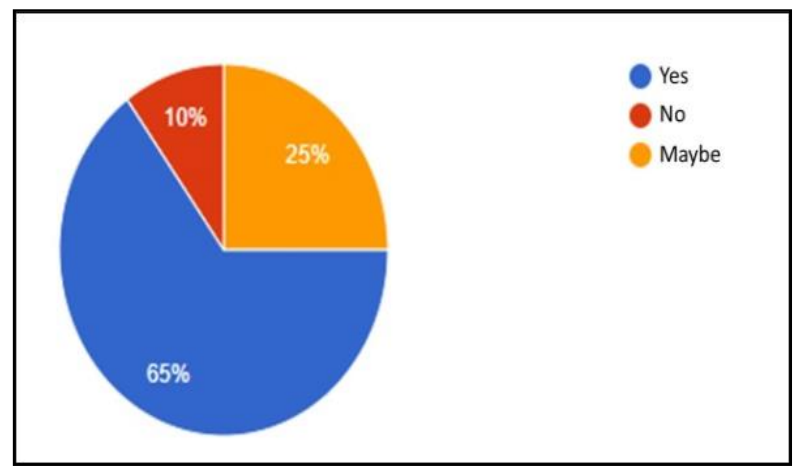

Figure 10 Survey Results of Respondents to Hotel Artotel

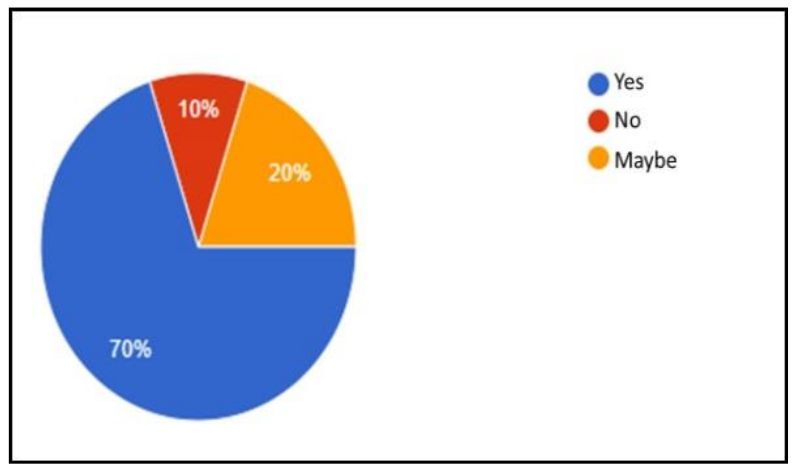

Figure 11 Survey Results of Respondents to Hotel Artotel

Based on the questionnaire given to 20 respondents, showing interest in the interior of the Bar and Lounge Hotel Artotel without the use of art in the interior is $67.5 \%$ and there are $10 \%$ of respondents who are not interested. Visitor interest in the interior of the Artotel Hotel bar and lounge with the use of art has decreased by $15 \%$.

\section{CONCLUSION}

In the research on the influence of contemporary art on the interior of bars and lounges, Hotel Artotel Thamrin, Jakarta, which aims to determine the influence of art on the interior of the bar and lounge, which is the attraction and image of the Hotel Artotel. Based on a survey conducted to 20 respondents with a questionnaire, the researcher concluded that Hotel Artotel cannot be separated from the use of art because the naming concept of Artotel which contains the word "Art" becomes an artistic hotel identity. Then the respondents are more interested in the interior of the Artotel Hotel bar and lounge with the use of $2 \mathrm{D}$ and $3 \mathrm{D}$ art. So that contemporary art becomes the identity and main focus of the Artotel Hotel interior.

That is the conclusion in the research on the influence of contemporary art on the interior of the Bar and Lounge Hotel Artotel Thamrin Jakarta. Researchers are aware that in this study there are many shortcomings and limitations in writing. However, researchers are trying to provide information to readers through this research. Hopefully this research can be useful to readers and through this research it can be continued with a better and more complete survey.

\section{REFERENCES}

[1] Anggraini, S. (2020, Januari 15). Nadiem Makarim: Seni penting untuk Pembangunan SDM Indonesia. Retrieved Desember 20, 2020, from Portal Teater: https://portalteater.com/nadiem-makarim-seni-pentinguntuk-pembangunan-sdm-indonesia/

[2] Bujung, L. A., Betteng, L., \& Erdiono, D. (2015). Galeri Seni Rupa 3 Dimensi Di Manado ( Ambiguitas Dalam Stylistika Arsitektur). Daseng, 184-191.

[3] Didit Endriawan, T. A. (2017). Mural sebagai Media Pendidikan dan Pengabdian Masyarakat. Seminar Nasional Seni dan Desain 2017, 482-485.

[4] Djojosudarmo, M. (2000). Apresiasi Karya Seni Modern dan Kontemporer. Jakarta: Balai Pustaka.

[5] Lawson, F. R. (1995). Hotel and Resort: Planning, Design and Refurbisment. London: Bath Press.

[6] Nazir, M. (2002). Metode Analisis Deskriptif. Yogyakarta: Erlangga.

[7] Rukajat, A. (2018). Pendekatan Penelitian Kuantitatif. Sleman: Deepublish.

[8] Sugiharito, B. (2013). Untuk Apa Seni, Seni dan Dunia Manusia. Bandung: Matahari. 
[9] Sugiyono. (2010). Metode Penelitian Pendidikan Pendekatan Kuantitatif, kualitatif, dan $R \& D$. Bandung: Alfabeta.

[10] Susanto, M. (2002). Diksi Rupa: Kumpulan Istilah Seni Rupa. Yogyakarta: Program Pasca Sarjana ISI Yogyakarta.

[11] Tabrani, P. D. (2000). Bahasa Rupa. Bandung: Kelir.

[12] Wicaksana, R. C. (2019). Dialektika Perkembangan Seni Rupa Kontemporer Dalam Budaya Visual Nusantara. Seminar Nasional Seni dan Desain : "Reinvensi Budaya Visual Nusantara", 349.

[13] Yana, D. (2014). Potensi Kerajinan Keramik Dalam Seni Tradisi Pertunjukan Indonesia. Panggung Vol. 24, 352-363. 